\title{
In vivo and in vitro genotoxicity studies of aqueous extract of Xanthium spinosum
}

\author{
Camila Martins Güez', Emily Pansera Waczuk², Karina Braccini Pereira ${ }^{1}$, Marcus Vinícius Morini \\ Querol $^{3}$, João Batista Teixeira da Rocha ${ }^{2}$, Luís Flávio Souza de Oliveira ${ }^{1, *}$
}

\author{
${ }^{1}$ Pharmacy Department, Federal University of the Pampa, ${ }^{2}$ Chemistry Department, Natural and Exacts Sciences Center, \\ Federal University of Santa Maria, ${ }^{3}$ Aquiculture Department, Federal University of the Pampa
}

\begin{abstract}
The use of plants as a source of palliative or cure for pathological conditions is quite common worldwide. Xanthium spinosum (Asteraceae), popularly known in Brazil as 'espinho de carneiro', is an annual weed from South America, which has been used by empiric medicine to treat neoplasias. Owing to the extensive use of the above-mentioned plant and to the lack of reports about the real effects of its infusion, current study evaluated the genotoxic potential of its aqueous extract at concentrations $0.02 \mathrm{~g} \mathrm{~L}^{-1}, 0.1 \mathrm{~g} \mathrm{~L}^{-1}$ and $0.2 \mathrm{~g} \mathrm{~L}^{-1}$ by fish micronucleus test and by comet human leukocytes assay. The micronucleus test featured at least 50 cells with micronuclei to every 2,000 cells scored, as a mutagenic parameter. The comet assay was used as a parameter for assessing the level of cell damage and the damage index. Since no significant changes in strain cells exposed to the aqueous extract in the comet and micronucleus assays were reported, it seems that no genotoxicity evidence is extant at the concentrations and in the assays performed.
\end{abstract}

Uniterms: Xanthium spinosum/pharmacognosy. Xanthium spinosum/aqueous extract/genotoxicity. Fish micronucleus assay. Comet assay.

Em diversos lugares do mundo a utilização de plantas como fonte paliativa ou de cura para determinadas condições patológicas é bastante comum. No Brasil, essa prática não se torna diferente devido à ampla biodiversidade da fauna e flora presentes no País. Nesse contexto, surge a Xanthium spinosum (Asteraceae), conhecida popularmente como "espinho-de-carneiro", um arbusto anual introduzido na América do Sul, o qual tem sido utilizado empiricamente no tratamento de neoplasias. Sabendo do extensivo uso dessa planta em contrapartida com nenhum estudo reportando os reais efeitos de sua infusão, o objetivo do estudo foi avaliar a genotoxicidade do extrato aquoso nas concentrações de $0,02 \mathrm{~g} \mathrm{~L}^{-1}$, $0,1 \mathrm{~g} \mathrm{~L}^{-1}$ e $0,2 \mathrm{~g} \mathrm{~L}^{-1}$, através do ensaio do micronúcleo písceo e do ensaio cometa em leucócitos de sangue humano. $\mathrm{O}$ ensaio do micronúcleo tem como parâmetro mutagênico a presença de no mínimo 50 células com micronúcleo em uma contagem de 2.000 células por amostra, enquanto o ensaio cometa utiliza como parâmetro o nível de dano e o índice de dano. Os resultados mostram que não foi possível observar mudanças significativas nas células expostas ao extrato aquoso, em ambos os testes, o que sugere não existir evidência de genotoxicidade nas concentrações utilizadas no ensaio.

Unitermos: Xanthium spinosum/farmacognosia. Xanthium spinosum/extrato aquoso/genotoxicidade. Ensaio do micronúcleo písceo. Ensaio cometa.

\section{INTRODUCTION}

The empirical knowledge on plants is a reflection of popular wisdom, with its ethnic references, throughout the history of civilization. In Brazil, up to the first half of

*Correspondence: L. F. S. Oliveira. Universidade Federal do Pampa-UNIPAMPA - 97500-970 - Uruguaiana - RS, Brazil. Telephone: 55 (55) 3413-4321, 55 (55) 9649-6574. E-mail: tcheluisoliveira@gmail.com the $20^{\text {th }}$ century, medicinal flora has been used on different occasions to treat several diseases (Lorenzi, Matos, 2002). This practice is foregrounded on the expensive prices of several medicines, which make them practically unavailable for the people (Simões et al., 2010).

Although the use of infusions is a common practice to treat or cure diseases, it is important to note that medicines manufactured from most plants in self-medication or through prescriptions fail to exhibit information on 
the toxicological profile or their safety in use (Bresolin, Vargas, 1993; Fernandes, Vargas, 2003, Capasso, 2000, Veiga Júnior, 2008). This is a fact of great concern since several studies show mutagenic (Cardoso et al., 2006; Déciga-Campos et al., 2007; Mohd-Fuat et al., 2007) and carcinogenic properties proper to some plants employed in empiric medicine (Sá Ferreira, Vargas, 1999).

On the other hand, according to the National Institute of Cancer (INCA), the state of Rio Grande do Sul has the highest incidence levels of cancer for 2010-2011. Skin cancer is top-ranked, followed by lung and prostate cancer for men, and breast and cervical cancer for women. Since a similar profile is observed for all Latin America (Ministério da Saúde, 2009), such data express clearly a public health problem.

Xanthium spinosum (Asteraceae), popularly known as 'espinho de carneiro', is an annual weed from South America, with an erect stalk, one meter high, densely branched, and featuring a branched taproot. The leaves' upper surface is shiny dark green, while the underside of the leaves is pale green and downy (Loretti, 1999; Miguel, 2004). This weed has been used by popular medicine in the form of infusions to treat several neoplasias in the region of the Brazilian pampas. However, as far as it is known, no document exists which indicate the plant's pharmacological or toxicological effects, although some reports on the genus Xanthium are extant which describe its pharmacological and toxicological properties, namely, cholinergic effects, kidney failure and acute hepatic necrosis (Matos et al., 2011).

Since it is widely used in the Brazilian pampas, current analysis tests the safety of Xanthium spinosum infusion by in vivo and in vitro genotoxicity studies.

\section{MATERIAL AND METHODS}

\section{Plant}

Samples of Xanthium spinosum were collected in April in the rural area of the Federal University of Pampa, Uruguaiana (RS), $29^{\circ} 45^{\prime} 23^{\prime \prime} \mathrm{S}$; $57^{\circ} 05^{\prime} 37^{\prime} \mathrm{W}$., and identified by Dr. Angelo Schneider, from Department of Botany, Federal University of Rio Grande do Sul, Porto Alegre RS Brazil, registered ICN 169161.

\section{Extract preparation}

The plant was initially dried in an incubator (Biopar S2OD model) for a few days until the root was completely dry, at a controlled temperature of $35^{\circ} \mathrm{C}$, and kept in a desiccator (Brasil, Ministério da Saúde, 2010).
The infusions were performed in three different concentrations $\left(0.02 \mathrm{~g} \mathrm{~L}^{-1}, 0.1 \mathrm{~g} \mathrm{~L}^{-1}\right.$, and $\left.0.2 \mathrm{~g} \mathrm{~L}^{-1}\right)$ using hot water $\left(70{ }^{\circ} \mathrm{C}\right)$ that was poured into a flask containing root samples previously triturated and weighted and then kept closed for 15 minutes. The determination of the final concentration was carried out by drying $1 \mathrm{~mL}$ of the infusion and left to dry in a controlled temperature of $30^{\circ} \mathrm{C}$ until constant weight. The final concentration was then measured.

\section{Comet assay samples}

Protocol 0089.0.243.000-07 was approved by the committee of UFSM for the undertaking of current assay.

Samples of venous blood were obtained from male adult volunteers (18-30 years old) attended to in the hospital of the Federal University of Santa Maria (UFSM), Santa Maria, RS, Brazil. Two milliliters of dextran 5\% were used to separate leukocytes of the heparinized blood sample $(8 \mathrm{~mL})$. The samples were then mixed and kept at room temperature for 45 minutes. The supernatant was centrifuged at 3,500 rpm for $10 \mathrm{~min}$ and the bottom layer formed was washed with a lysis solution when the layer began to appear yellow. The bottom layer was suspended in $2 \mathrm{~mL}$ Hank's buffer solution saline and adjusted to $2 \times 10^{3}$ leukocytes/mL with HBSS/heparin.

The blood samples were assayed by the comet assay under alkaline conditions, following procedures by Santos et al. (2009). Peripheral leukocytes were incubated during 3 hours with the extract at three different concentrations, $0.02 \mathrm{~g} \mathrm{~L}^{-1}, 0.1 \mathrm{~g} \mathrm{~L}^{-1}$ and $0.2 \mathrm{~g} \mathrm{~L}^{-1}$, the latter two being five and ten times more concentrated than normal when the plant is used. Whereas distillated $\mathrm{H}_{2} \mathrm{O}$ was used as negative control, $\mathrm{H}_{2} \mathrm{O}_{2} 4 \mathrm{mM}$ was the positive control. After incubation, leukocytes were mixed with low-melting point agarose, of which $90 \mu \mathrm{L}$ were added to $15 \mu \mathrm{L}$ of the leukocyte solution and placed on a microscope slide pre-coated with normal melting point agarose $1.0 \%$. A coverslip was added and the slides were placed on ice during 5 minutes. After solidification, the coverslips were removed and the slides were immersed in a lysis solution. The slides were kept frozen in the lysis solution $\left(4^{\circ} \mathrm{C}\right)$ and protected from light for approximately 14 hours. They were subsequently incubated in freshly prepared alkaline buffer for 20 minutes for DNA unwinding. Electrophoresis (20 min at $300 \mathrm{~mA}$ and $25 \mathrm{~V}$ ) was performed in the same buffer. Each stage was performed under indirect yellow light. After electrophoresis, the slides were neutralized in Tris $400 \mathrm{mM}$ (pH 7.5), rinsed three times in distilled water, and left to dry overnight at room temperature. The dry slides were re-hydrated for $3 \mathrm{~min}$ in distilled water and then fixed 
for $10 \mathrm{~min}$, rinsed three times in distilled water, and dried for at least $5 \mathrm{~h}$. The dry slides were re-hydrated for $3 \mathrm{~min}$ in distilled water, stained, and constantly shaken for 25 $\min$. The slides submerged in the stop solution were rinsed again and immediately tagged for analysis. The slides were analyzed under blind conditions by at least two individuals. DNA damage is given as DNA damage index (DI). The DNA damage was calculated from cells in different damage classes (completely undamaged: 100 cells $\times 0$ to maximum damaged -100 cells $\times 4$ ).

\section{Cell viability}

Cell viability assay was carried out by Mischell and Siingi method (1980), with slight modifications. Cells were exposed to the same concentration of both compounds for 3 hours, as in the comet test. After the incubation, $40 \mathrm{~mL}$ of a cell suspension were mixed with $30 \mathrm{~mL}$ of buffer HBBS and $50 \mathrm{~mL}$ of Trypan Blue solution $0.4 \%$ for $8 \mathrm{~min}$. Cell viability was determined microscopically $(400 \times$ magnification) and two categories of cells were scored: (1) live cells, which appeared uncolored or light blue, (2) dead cells, with a blue color.

\section{Micronuclei assay in fish erythrocytes}

To evaluate genotoxicity using the micronucleus assay, specimens of Astyanax bimaculatus, popularly known as 'lambari', were collected from the breeding tanks of the Núcleo de Pesquisa Ictiológicas, Limnológicas e Aquicultura da Bacia do Rio Uruguai (NUPILABRU), in Uruguaiana, RS, Brazil. The fish $(\mathrm{n}=32)$ were randomly distributed in four different $50 \mathrm{~L}$ aquariums. Groups $(\mathrm{n}=8$ for each) were divided into control group and test groups (EC1, EC2, and EC3) and treated with three different concentrations of an aqueous extract $\left(0.02 \mathrm{~g} \mathrm{~L}^{-1}\right.$ to $\mathrm{EC} 1$; $0.1 \mathrm{~g} \mathrm{~L}^{-1}$ to EC2; $0.2 \mathrm{~g} \mathrm{~L}^{-1}$ to EC3). The animals were kept in contact with the extract during 72 hours. Temperature, $\mathrm{pH}$, resistivity, conductivity, salinity and oxygen levels were controlled throughout the experiment (Delincé, 1992).

After treatment, blood samples were collected from all fish and an extension in glass slide was made for each sample, according to technique by Heddle (1973).

After drying, the slide was fixed in ethanol PA (MERCK ${ }^{\circledR}$ ) for 30 minutes. Slides were stained by Panótico Rápido ${ }^{\circledR}$ (Labor Clean) and then analyzed under optical microscopy (Olympus) in immersion lens. Further, 2000 cells were counted so that the slide would identify the micronucleus (Campana et al., 1999; Grisolia, 2002). All particles clearly separated from the principal core, not exceeding $1 / 3$ of their real size, with visible borders, same color and refringent from core, were considered micronuclei. So that a substance or chemical may be mutagenic, it must cause the appearance of at least 50 cells with micronuclei to every 2000 cells scored (Carrasco et al., 1990).

\section{Statistical analysis}

Data from damage levels were analyzed by Twoway ANOVA and index damage by One-way ANOVA; post-hoc were Bonferroni and Newman-Keuls Multiple Comparison Test, respectively ( $\mathrm{p}<0.001$ was considered significantly different). Data from micronucleus assay were analyzed by One-way ANOVA; post-hoc NewmanKeuls Multiple Comparison Test $(\mathrm{p}<0.001$ was considered significantly different). All analyses were performed by BioEstat 5.0, at http://www.firstload.com/search. php?q=download bioestat 50 .

\section{RESULTS AND DISCUSSION}

Figure 1 shows the percentage of viable cells for both negative control group and for the three group tests $(100 \%)$, each with different extract concentrations. This is not applicable to the positive control (85\%) which, as

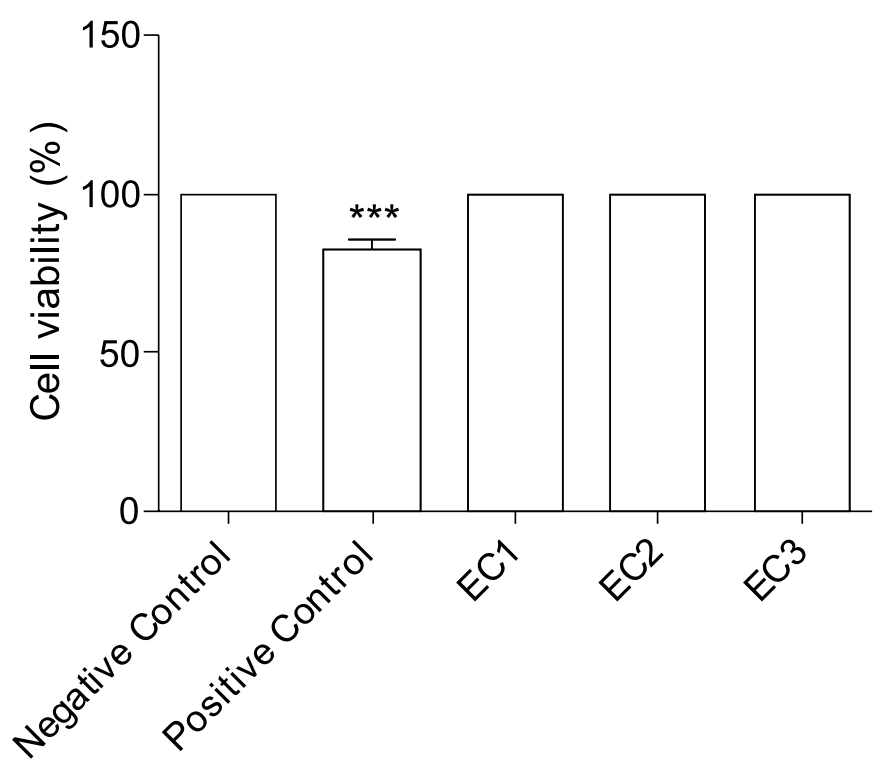

FIGURE 1 - Comet cell viability from the aqueous extract of Xanthium spinosum in three different concentrations in which positive control was different from the others, negative control and extract concentrations ( $* * * \mathrm{p}<0.001)$. One-way ANOVA and post-hoc Newman-Keuls Multiple Comparison Test). Data are expressed as percentage; $\mathrm{n}=4$. $\mathrm{EC}=$ extract concentration, $\mathrm{EC} 1=0.02 \mathrm{~g} \mathrm{~L}^{-1} ; \mathrm{EC} 2=0.1 \mathrm{~g} \mathrm{~L}^{-1} ; \mathrm{EC} 3=0.2 \mathrm{~g} \mathrm{~L}^{-1}$. 
a whole, demonstrated the right conditions to perform the comet assay. According to Collins et al. (2008), high viability is required as a previous condition for the performance of the comet assay. It is highly relevant to note that the lowest concentration used (EC1) denotes the amount for empiric use, whereas the other extract concentrations, EC2 and EC3 were respectively five and ten times higher than the lowest concentration.

Table I and Figure 2 show low-level damage by the plant extract in the three different concentrations used. As may be observed, the lowest concentration $\left(0.02 \mathrm{~g} \mathrm{~L}^{-1}\right)$ was similar to that found in negative control (Table 1), whereas the other concentrations $\left(0.1 \mathrm{~g} \mathrm{~L}^{-1}\right.$ and $\left.0.2 \mathrm{~g} \mathrm{~L}^{-1}\right)$ were close to the above. Similarly, damage indexes showed low levels at the concentrations tested. Indeed, there was no significant statistical difference at concentration $0.02 \mathrm{~g} \mathrm{~L}^{-1}$ when compared to that in negative control. Although the damage indexes presented at concentrations $0.1 \mathrm{~g} \mathrm{~L}^{-1}$ and $0.2 \mathrm{~g} \mathrm{~L}^{-1}$ were higher than that of negative control and the $0.02 \mathrm{~g} \mathrm{~L}^{-1}$ concentration, they were significant and statistically lower than positive control.

It is well documented in the literature that genetic mutations act by different steps on the carcinogenesis process and some tests, such as the comet assay, identify genotoxic agents and substances with potential risks to the human health. Genotoxic substances have in common chemical and physical properties that allow the interaction of nucleic acids. The most relevant consequence of these alterations in somatic cells may be the presence of benign or malignant tumors (De Flora et al., 1996; Andreassi et al., 2000; Aruoma, 2003; Ross, Margolis, 2005).

These findings suggest that the plant extract used does not provide significant injury to genetic cellular apparatus, especially at concentration $0.02 \mathrm{~g} \mathrm{~L}^{-1}$, since no DNA fragments form the 'comet'. The above indicates low genotoxicity for the different concentrations on human leukocyte DNA, at least in the experimental conditions tested. Moreover, considering that the $0.02 \mathrm{~g} \mathrm{~L}^{-1}$ concentration corresponds to that used by non-traditional medicine and does not reflect bioavailability concentration on individuals after the intake of the infusion, its safety becomes even more significant. Furthermore, even the other concentrations tested seem to provide relative safety in use, even though they are five and ten times higher than the concentration used by non-traditional medicine.

Figure 3 shows the number of micronucleus found at the three concentrations of plant extract under analysis. The micronucleus assay did not reveal any statistically significant difference between the groups. Moreover, data clearly demonstrated that there was no mutagenic effect in the tested extract concentrations since all the results revealed less than 50 micronuclei per sample analyzed.

According to Hoofman and Raat (1982), the micronuclei assay in fish erythrocytes may be an alternative for chromosomal aberrations and mutagenic damages that may be evaluated by several methods. Among the cytogenetic methods, the micronuclei assay in erythrocytes is a simple, reliable and sensitive technique (Klingerman,

TABLE I - Comet Assay: Frequency of damage levels and index damage from the aqueous extract of Xanthium spinosum, in three different concentrations

\begin{tabular}{lccccccc}
\hline Treatment & Concentration & \multicolumn{5}{c}{ Levels of damage } & DI \\
\cline { 2 - 7 } & & 0 & 1 & 2 & 3 & 4 & \\
\hline Negative Control & 0 & $91.25 \pm 1.25$ & $9.25 \pm 2.39$ & $1.25 \pm 0.69$ & $0 \pm 0.0$ & $0 \pm 0.0$ & $11.75 \pm 2.68$ \\
Positive Control & $4 \mathrm{mM}$ & $11.5 \pm 4.11^{\mathrm{a}}$ & $7.75 \pm 1.79$ & $17 \pm 2.5^{\mathrm{a}}$ & $26 \pm 2.27^{\mathrm{a}}$ & $37.75 \pm 7.88^{\mathrm{a}}$ & $282.8 \pm 17.37^{\mathrm{a}}$ \\
Xanthium spinosum & $0.02 \mathrm{~g} . \mathrm{L}^{-1}$ & $92.75 \pm 1.49^{\mathrm{b}}$ & $6 \pm 1.08$ & $1 \pm 0.4^{\mathrm{b}}$ & $0.25 \pm 0.25^{\mathrm{b}}$ & $0 \pm 0.0^{\mathrm{b}}$ & $8.750 \pm 2.13^{\mathrm{b}}$ \\
extract & 0.1 g.L $\mathrm{L}^{-1}$ & $84.5 \pm 2.06^{\mathrm{ab}}$ & $9.5 \pm 1.55^{\mathrm{b}}$ & $3.75 \pm 1.10^{\mathrm{ab}}$ & $0.75 \pm 0.25^{\mathrm{ab}}$ & $0 \pm 0.0^{\mathrm{b}}$ & $19.25 \pm 2.68^{\mathrm{ab}}$ \\
& 0.2 g.L $^{-1}$ & $87.75 \pm 1.93^{\mathrm{ab}}$ & $8.75 \pm 1.93^{\mathrm{b}}$ & $2.75 \pm 0.47^{\mathrm{ab}}$ & $0.5 \pm 0.28^{\mathrm{ab}}$ & $0 \pm 0.0^{\mathrm{b}}$ & $16.75 \pm 2.83^{\mathrm{b}}$ \\
\hline
\end{tabular}

Damage levels from aqueous extract of Xanthium spinosum (Two-way ANOVA; post-hoc Bonferroni); DI = Damage Index (One-way ANOVA; post hoc Newman-Keuls Multiple Comparison Test). Data are expressed as mean $\pm \mathrm{SEM}, \mathrm{n}=4$; ${ }^{\mathrm{a}}$ Statistically significant difference when compared to negative control; ${ }^{\mathrm{b}}$ Statistically significant difference when compared to positive control.

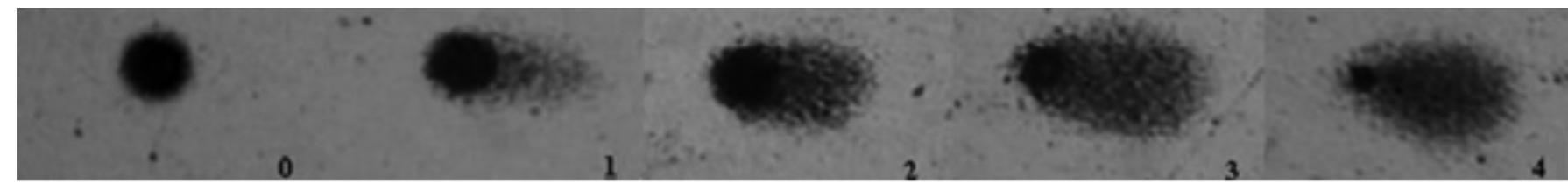

FIGURE 2 - Damage class levels of $\mathrm{H}_{2} \mathrm{O}_{2}$ from 0 to 4 in comet assay. 


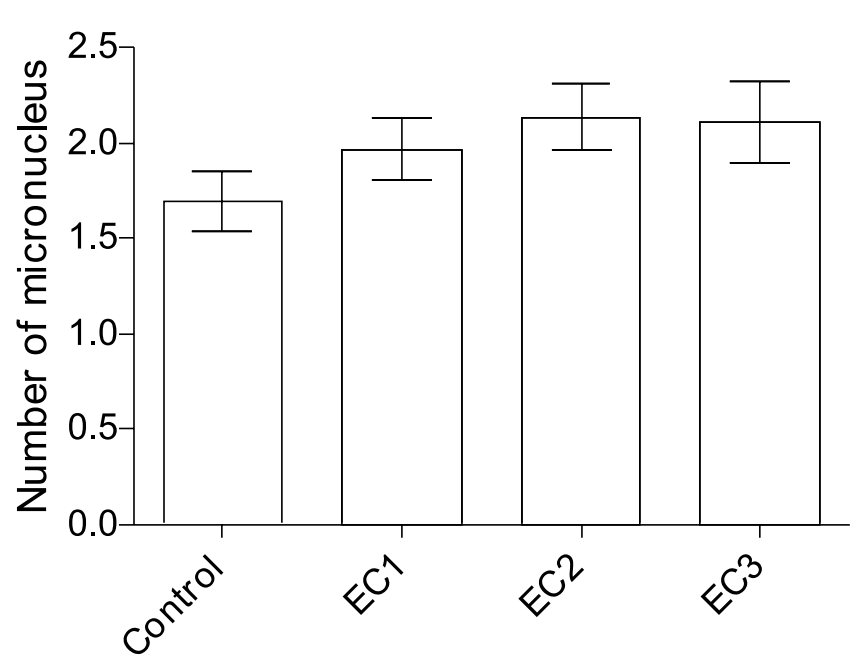

FIGURE 3 - Number of fish micronucleus after exposition to three different concentrations of the aqueous extract of Xanthium spinosum (One-way ANOVA; post-hoc Newman-Keuls Multiple Comparison Test, $\mathrm{p}<0.001)$. Data are expressed as mean $\pm \mathrm{SEM}$ of 8 animals per group. $\mathrm{EC}=$ extract concentration, $\mathrm{EC} 1=0.02 \mathrm{~g} \mathrm{~L}^{-1} ; \mathrm{EC} 2=0.1 \mathrm{~g} \mathrm{~L}^{-1} ; \mathrm{EC} 3=0.2 \mathrm{~g} \mathrm{~L}^{-1}$.

1982), applied to any fish species regardless of karyotype characteristics (Hose et al., 1987).

The genotoxic potential of several substances may be detected and quantified using fish as the experimental model, since these animals, similar to mammals, may activate the enzymatic system from cytochrome P450 (Goksoyr et al., 1991; Andrade et al., 2004). Furthermore, spontaneous formation of micronuclei is normally low and nearly uniform among species. Thus, the action of any genotoxic agent may give rise to an increase in micronucleus frequency (Siu et al., 2004).

Another interesting point is that in the literature the toxicity attributed to some plants of the Asteraceae family, such as Atractylis gummifera L., Xanthium cavanillesii Schouw and Xanthium strumarium L., is connected to carboxyatractyloside found only in fruits and grains, and absent in other parts of the plant, such as roots and leaves (Obatomi, Bach, 1998; Driemeier et al., 1999; Hamouda et al., 2004; Daniele et al., 2005; Turgut et al., 2005). These data might be partially connected to the low toxicity shown by the extract concentration of $X$. spinosum when the comet and the micronucleus assays were employed since the root was the part of plant used.

\section{CONCLUSIONS}

Results by micronucleus assay suggest that the different concentrations of the aqueous extract of $X$. spinosum tested showed no mutagenic effect for fish erythrocytes. Furthermore, the comet assay in human leukocyte cells showed that there was no DNA damage in the lowest concentration of the extract tested. However, low damage level was detected in the other two concentrations tested.

\section{REFERENCES}

ANDRADE, V.M.; FREITAS, T.R.O.; SILVA, J. Comet assay using mullet (Mugilsp.) and sea catfish (Netumasp.) erythrocytes for the detection of genotoxic pollutants in aquatics environment. Mutat. Res., v.560, n.1, p.57-67, 2004.

ANDREASSI, M.G.; BOTTO, N.; COLOMBO, M.G.; BIAGINI, A.; CLERICO, A. Genetic instability and atherosclerosis: can somatic mutations account for the development of cardiovascular diseases? Environ. Mol. Mutagen., v.35, n.4, p.265-269, 2000.

ARUOMA, O.I. Methodological considerations for characterizing potential antioxidant actions of bioactive components in plant foods. Mutat. Res., v. 523-524, p.920, 2003.

BRASIL. MINISTÉRIO DA SAÚDE. Agência Nacional de Vigilância Sanitária (ANVISA). Farmacopeia Brasileira 2010, Brasília. Available at: <http://www.anvisa.gov.br/ hotsite/farmacopeia/index.htm>. Acessed on: 2 jul. 2011.

BRASIL. MINISTÉRIO DA SAÚDE. Instituto Nacional de Câncer. Estimativa 2010: Incidência de câncer no Brasil / Instituto Nacional de Câncer. Rio de Janeiro: INCA, 2009. Avaliable at: <http://www.inca.gov.br/estimativa/2010. index.asp?link $=$ conteudo_view.asp $\& I D=5$. Acessed on: 10 jul. 2011.

BRESOLIN, S.; VARGAS, V.M.F. Mutagenic potencies of medicinal plants screened in the Ames test. Phytoth. Res., v.7, n.3, p.260-262. 1993.

CAMPANA, M.A.; PANZERI, A.M.; MORENO, V.J.; DULOUT, F.N. Genotoxic evaluation of the pyrethroid lambda-cyhalothrin using the micronucleus test in erythrocytes of the fish Cheirodon interruptus. Mutat. Res., v.438, n.2, p.155-161, 1999.

CAPASSO, R.; IZZO A.A.; PINTO L.; BIFULCO T.; VITOBELlO, C.; MASCOLO, N. Phytotherapy and quality of herbal medicines. Fitoterapia, v.71, n.1, p.5865,2000 . 
CARDOSO, C.R.P.; DE SYLLOS CÓLUS, I.M.; BERNARDI, C.C.; SANNOMIYA, M.; VILEGAS, W.; VARANDA, E.A. Mutagenic activity promoted by amentoflavone and methanolic extract of Byrsonima crassa Niedenzu. Toxicology, v.225, n.1, p.55-63, 2006.

CARRASCO, K.R.; TILBURY, K.L.; MYERS, M.S. Assessment of the piscine micronucleus test as an in situ biological indicator of chemical contaminants effects. Can. J. Fish.Sci., v.47, n.11, p.2123-2136, 1990.

COLLINS, A.R.; OSCOZ, A.A.; BRUNBORG, G.; GAIVÃO, I.;GIOVANNELLI, L.; KRUSZEWSKI, M.; SMITH, C.C.; STETINA, R. The comet assay: topical issues. Mutag., v.23, n.3, p.143-151, 2008.

DANIELE, C.; DAHAMNA, S.; FIRUZI, O.; SEKFALI, N.; SASO, L.; MAZZANTI, G. Atractylis gummifera L. poisoning: an ethnopharmacological review. $J$. Ethnopharmacol., v.97, p.175-181, 2005.

DEFLORAS.; IZZOTTI,A.; RANDERATH, K.; RANDERATH, E.; BARTSCH, H.; NAIR, J.; BALANSKY, R.; VAN SCHOOTEN, F.; DEGAN, P.; FRONZA, G.; WALSH, D.; LEWTAS, J. DNA adducts in chronic degenerative diseases. Pathogenic relevance and implications in preventive medicine. Mutat. Res., v.366, n.3, p.197-238, 1996.

DÉCIGA-CAMPOS, M.; RIVERO-CRUZ, I.; ARRIAGAALBA, M.; CASTAÑEDACORRAL, G.; ANGELESLÓPEZ, G.E.; NAVARRETE, A.; MATA, R. Acute toxicity and mutagenic activity of Mexican plants used in traditional medicine. J. Ethnopharmacol., v.110, n.2, p.334-342, 2007.

DELINCÉ, G. The ecology of the fish pond ecosystem with special reference to Africa. Dordrecht: Kluwer, $1992.232 \mathrm{p}$.

DRIEMEIER, D.; IRIGOYEN, L.F.; LORETTI, A.P.; COLODEL, E.M.; BARROS, C.S.L. Intoxicação espontânea pelos frutos de Xanthium cavanillesii (Asteraceae) em bovinos no Rio Grande do Sul. Pesq. Vet. Bras., v.19, n.1, p.12-18, 1999.

FERNANDES, J.B.F.; VARGAS, V.M.F. Mutagenic and antimutagenic potential of the medicinal plants $M$. laevigata and C. xanthocarpa. Phytoth. Res., v.17, n.3, p.269-273. 2003.

GRISOLIA, C.K.A. Comparison between mouse and fish micronucleus test using cyclophosphamide, mitomycin $\mathrm{C}$ and various pesticides. Mutat. Res., v.518, n.2, p.145-150, 2002.
GOKSOYR,A.;ANDERSON, T.; BUHLER, D.R.; STEGEMAN, JJ.; WILLIANS, D.E.; FORLIN, L. Immunochemical crossreactivity of $\beta$-naphthoflavone-inducible cytocrome P450 in liver microsomes from different fish species and rat. Fish Phys., v.9, n.1, p.1-13, 1991.

HEDDLE, J.A. A rapid in vivo test for chromosomal damage. Mutat. Res., v.18, n.2, p.187-190, 1973.

HOOFMAN, R.N.; RAAT, W.K. Induction of nuclear anomalies (micronuclei) in the peripheral blood erythrocytes of the eastern mud minnow Umbra pigmaea by ethyl methanesulphonate. Mutat. Res., v.104, n.1-4, p.147-152, 1982.

HOSE, J.E.; CROSS, J.N.; SMITR, S.G.; DIEHL, D. Elevated circulating erythrocytes micronuclei in fishes from contaminated sites of southern California. Marine Environ. Res., v.22, n.3, p.167-176, 1987.

HAMOUDA, C.; HÉDHILI, A.; BEM-SALAH, N.; ZHIOUA, M.; AMAMOU, M. A review of acute poisoning from Atractylis gummifera L. Vet. Hum. Toxicol., v.46, n.3, p.144-146, 2004.

KLIGERMAN, A.D. Fishes as biological detector of the effects of genotoxic agents. In: HEDDLE J. A. (Ed.). Mutagenicity: new horizonts in genetics toxicology. New York: Academic Press, 1982. p.435-456.

LORENZI, H.; MATOS, F.J.A. Plantas medicinais no Brasil: nativas e exóticas. 2.ed. São Paulo: Editora Plantarum, 2002. 544 p.

LORETTI, A.P.; BEZERRA, P.S.; ILHA, M.R.S.; BARROS, S.S.; BARROS, C.S L. Intoxicação experimental pelos frutos de Xanthium cavanillesii (Asteraceae) em ovinos. Pesq. Vet. Bras., v.19, n.2, p.71-78, 1999.

MATOS , F.J.A.; LORENZI, H.; SANTOS, L.F.L.; MATOS, M.E.O.; SILVA, M.G.V.; SOUZA, M.P. Plantas tóxicas. Estudo de fitotoxicologia química de plantas brasileiras. São Paulo: Editora Plantarum, 2011. p.50-51.

MIGUEL, M.D.; MIGUEL, O. Desenvolvimento de fitoterápicos. 2.ed. São Paulo: Tecmed, 2004. 115 p.

MISCHELL, B.B.; SIINGI, S.M. Selected methods in cellular immunology. San Francisco: W.H. Freeman Company, 1980. 486 p. 
MOHD-FUAT, A.; KOFI, E. Mutagenic and cytotoxic properties of three herbal plants from Southeast Asia. Trop. Biomed., v.24, n.2, p.49-59, 2007.

OBATOMI, D.K.; BACH, P.H. Biochemistry and toxicology of the diterpenoid glycoside atractyloside. Food Chem. Toxicol., v.36, n.3, p.335-346, 1998.

ROSS, C.A.; MARGOLIS, R.L. Neurogenetics: insights into degenerative diseases and approaches to schizophrenia. Clin. Neurosc. Res., v.5, n.1, p.3-14, 2005.

SÁ-FERREIRA, I.C.F.; VARGAS, V.M.F. Mutagenicity of medicinal plant extracts in Salmonella/microsome assay. Phytoth. Res., v.13, n.5, p.397-400. 1999.

SANTOS, D.B.; SCHIAR, V.P.P.; PAIXÃO, M.W.;MEINERZ, D.F.; NOGUEIRA, C. W.; ASCHNER, M.;ROCHA, J.B.T.;BARBOSA, N.B.V. Hemolytic and genotoxic evaluation of organochalcogens in human blood cells in vitro. Toxicol. in Vitro, v.23, n.6, p.1195-1204, 2009.
SIMÕES, C.M.O.; SCHENKEL, E.P.; GOSMANN, G.; MELLO, J.C.P.; MENTZ, L.A.; PETROVICK, P.R. Farmacognosia: da planta ao medicamento. 6.ed. Porto Alegre/Florianópolis: Ed. da UFRGS/Ed. UFSC, 2010. $1104 \mathrm{p}$.

SIU, W.H.L.; MAK, E.; JIA, C.; DE LUCA-ABBOTY, S.B.; RICHARDSON, B.J.; LAM, P.K.S. Micronucleus induction in gill cells of green-lipped mussels (Pernaviridis) exposed to mixtures of polycyclic aromatic hydrocarbons and chlorinated pesticides. Environ. Toxicol. Chem., v.232, n.5, p.1317-1325, 2004.

TURGUT, M.; ALHAN, C.C.; GÜRGÖZE, M.; KURT, A.; DOĞAN, Y.; TEKATLI, M.; AKPOLAT, N.; AYGÜN, A.D. Carboxyatractyloside poisoning in humans. Ann. Trop. Paed., v.25, n.2, p.125-134, 2005.

VEIGA-JUNIOR, V.F. Estudo do consumo de plantas medicinais na Região Centro-Norte do Estado do Rio de Janeiro: aceitação pelos profissionais de saúde e modo de uso pela população. Rev. Bras. Farmacogn., v.18, n.2, p.308-313, 2008.

Received for publication on $02^{\text {nd }}$ June 2011 Accepted for publication on $24^{\text {th }}$ May 2012 
